Full-text Available Online at www.ajol.info and www.bioline.org.br/ja

\title{
Stem Bark Extracts of Ficus exasperata protects the Liver against Paracetamol induced toxicity in Wistar Rats
}

\author{
${ }^{* 1}$ ENOGIERU, AB; ${ }^{1}$ CHARLES, YO; ${ }^{1}$ OMORUYI, SI; ${ }^{1}$ MOMODU, OI; ${ }^{1}$ EZEUKO, VC \\ ${ }^{I}$ Department of Anatomy, School of Basic Medical Sciences, College of Medical Sciences, University of Benin, Benin City, Edo State, Nigeria \\ Corresponding Author: Enogieru, AB Email: bizou.enogieru@uniben.edu
}

KEYWORDS: Ficus exasperata, Paracetamol, Silymarin, hepatoprotective, Histology

\begin{abstract}
Ficus exasperata is an important medicinal plant with a wide geographical distribution in Africa particularly in Nigeria. In this study, aqueous stem bark extracts of Ficus exasperata were administered to investigate its hepatoprotective effects on Paracetamol induced liver toxicity in Wistar rats. A total of Twenty Five Wistar rats were randomly divided into five groups labeled A-E and kept in a well ventilated room. Group A served as control and were treated with distilled water. Rats in groups B-E were all treated with Paracetamol $(800 \mathrm{mg} / \mathrm{kg}$ body weight) but rats in group C, D and E were however pretreated with Silymarin $(50 \mathrm{mg} / \mathrm{kg}$ bw), $100 \mathrm{mg} / \mathrm{kg}$ bw aqueous stem bark extracts of Ficus exasperata and $200 \mathrm{mg} / \mathrm{kg}$ bw aqueous stem bark extracts of Ficus exasperata respectively one hour before Paracetamol administration for fourteen days. Animals were sacrificed twenty four hours after the last treatment. Blood samples were collected into heparinized bottles for biochemical estimation of liver enzymes and the liver was harvested for routine histological examination. Paracetamol produced significant changes in biochemical parameters (increases in serum Alanine Aminotransferase (ALT), Aspartate Aminotransferase (AST), Alkaline Phosphatase (ALP), with a reduction in Total protein) and Liver histology (damage to hepatocytes). Pretreatment with Silymarin and aqueous stem bark extracts of Ficus exasperata significantly prevented the biochemical and histological changes induced by Paracetamol in the liver. In conclusion, our histological and biochemical findings indicate that aqueous stem bark extracts of Ficus exasperata possesses hepatoprotective properties. () JASEM
\end{abstract}

\section{http://dx.doi.org/10.4314/jasem.v19i1.20}

Introduction: The Liver is a key organ in the human body and is a frequent target for a number of toxicants (Meyer et al., 2001). Liver damage due to hepatotoxic agents is of dire consequences, prompting an ever increasing need of an agent which could protect it from such damage. There is a worldwide trend to go back to traditional medicinal plants in the treatment of liver diseases as synthetic drugs used in the treatment of liver diseases have serious adverse side effects and are often times inadequate (Mitra et al. 2000).

Ficus exasperata Vahl (Moraceae) is an important medicinal plant with a wide geographical distribution in Africa particularly in Nigeria. (Hallan, 1999; Abbiw, 1990). In Nigeria there are over 45 different species of Ficus (Keay, 1964), such as Ficus glomosa, Ficus lecardi, Ficus goliath, Ficus capensis, Ficus ingens and Ficus elastica, which can be found besides rivers and streams and also in the Savannah, rainforest. The leaves are oval, it has elliptic leaves with a very rough surface and are alternately arranged making them look like sand paper. Ficus exasperata (Vahl) is commonly known as sand paper tree ("Ewe Ipin") in
Yoruba. Other various local names include; Anwerenwa (Igbo), Erepin (Yoruba), Kawusa (Nupe), Ameme (Edo), (Bafor et al. 2009).

The leaf extract from Ficus exasperata is reported to have diverse uses such as treating hypertensive patients (Buniyamin et al. 2007), coughs and heamorrhoid (Odunbaku et al. 2008). Numerous pharmacological actions such as lipid lowering, antidiabetic and antifungal activities have been reported for Ficus exasperata (Sonibare et al. 2006), and more recently the use of Ficus exasperata for treating several problems like difficult child birth, bleeding and diarrhoea in traditional medicine was reported (Ijeh and Agbor 2006). It is also used for treating various infections and as sand paper for polishing woods (Cousins and Micheal 2002).

\section{MATERIALS AND METHOD}

Plant Material: The Stem bark of Ficus exasperata were collected from the University of Benin environment, in Benin City, Nigeria and was identified and authenticated by Mr. Sunny Nweke of the 
Department of Pharmacognosy, Faculty of Pharmacy, University of Benin.

Preparation Of Extract: The stem bark of Ficus exasperata were washed with normal saline, air dried at room temperature and protected from direct sunlight for two weeks. The air-dried specimens were then pulverized using the laboratory hammer-mill and the powdered samples were stored in air and water-proof containers until required for extraction. $2.0 \mathrm{~kg}$ of the powdered stem bark of Ficus exasperata was extracted in distilled water by percolation for 24 hours. The mixture was filtered using Whatmann filtered paper and the filtrate evaporated at $60^{\circ} \mathrm{C}$ using a vacuum Rotary evaporator. An aliquot portion of the extract residue was stored in a refrigerator and a measured portion was dissolved in distilled water for use on each day of the experiment.

Animal Care: The School of Basic Medical Sciences, University of Benin granted approval before the work commenced. The adult male Wistar rats weighing between 230-260g were obtained and maintained in the Animal Holdings of the Department of Anatomy, School of Basic Medical Sciences, University of Benin, Benin city, Edo State, Nigeria. The animals were fed with grower's mash obtained from Edo Feeds and Flour Mill Limited, Ewu, Edo State, Nigeria and given feeds liberally.

Drugs And Dosing Schedule: The Wistar rats were divided into five Groups; Group A (Control), Group B (Paracetamol treated), Group C (Paracetamol + Silymarin treated), Group D and E (Paracetamol + Extract). Rats in group A served as the control group and were given distilled water.. Rats in groups B were administered Paracetamol only at $800 \mathrm{mg} / \mathrm{kg}$ body weight per day for fourteen days consecutively via the oral route. Simultaneously but at different hours of the day, rats in groups $\mathrm{C}, \mathrm{D}$ and $\mathrm{E}$ were administered with Silymarin $(50 \mathrm{mg} / \mathrm{kg})$, aqueous stem bark extracts of Ficus exasperata in doses of $100 \mathrm{mg} / \mathrm{kg}$ and 200 $\mathrm{mg} / \mathrm{kg}$ body weight respectively an hour before administration of Paracetamol $(800 \mathrm{mg} / \mathrm{kg}$ body weight, orally) via the orogastric tube for fourteen days consecutively.

Sacrifice of animals: At the end of the experimental period, the rats were grossly observed for general physical characteristics. Rats were sacrificed by anaesthesia with ketamine and a midline incision was made through the anterior abdominal wall. The liver was isolated from the surrounding organs and fixed in
Bouin's fluid for 48 hours for routine histological examination.

Biochemical Estimations: Blood samples were collected from the rats, transferred to anticoagulant sample bottles smeared with lithium-heparin. The blood samples were centrifuged in a Denley BS400 centrifuge (England) for $5 \mathrm{mins}$ at $5000 \mathrm{rpm}$ to obtain serum. Serum obtained was used for estimation of Alanine Amino Transferase (ALT), Aspartate Amino Transferase (AST), Alkaline Phosphatase (ALP) and Total protein (TP) using Random diagnostic kits (Reitman et al., 1957).

Histological Procedure: The liver tissue was processed via the paraffin wax embedding method of Drury and Wallington (Drury et al. 1976). Serial sections of $5 \mu \mathrm{m}$ thick were obtained using a rotatory microtome. The deparaffinized sections were stained routinely with Haematoxylin and Eosin (H\&E) for light microscopic examination of the liver tissue architecture. Photomicrographs of the results were obtained using research photographic microscope in the Department of Anatomy, School of Basic Medical Sciences, University of Benin, Benin city, Edo State, Nigeria.

Statistical Analysis: Statistical analysis was carried out using Statistical Package for Social Sciences (SPSS, version 16, Chicago, IL). The data were analysed using descriptive and inferential statistics. All values were presented as mean \pm standard error of mean (SEM). The significance of difference in the means of all parameters was determined using one way analysis of variance (ANOVA; 95\% confidence interval). When Analysis of Variance was statistically significant, Least Square difference post hoc test was carried out for all groups compared with control group and comparison of all pairs of groups respectively.

\section{RESULTS AND DISCUSSION}

Table 1 shows the effects of Paracetamol, Silymarin, and different doses of Ficus exasperata extracts on the activity of AST, ALT, ALP and TP respectively in the serum of experimental groups A-E. The activity of AST, ALT and ALP significantly increased $(\mathrm{p}<0.05)$ in Paracetamol treated rats (Group B) when compared to the control. The activity of these enzymes is significantly lowered in the Silymarin + Paracetamol treated group C, Ficus exasperata + Paracetamol treated groups D and E. Furthermore, the activity of TP is significantly $(\mathrm{p}<0.05)$ reduced in Paracetamol treated rats (Group B) when compared to the control group A and treated groups D-E. 
Table 1: Effects of Ficus exasperata on liver enzymes and serum total protein of rats in experimental groups.

\begin{tabular}{llllll}
\hline Groups & $\begin{array}{l}\text { Group A } \\
\text { (Control) }\end{array}$ & $\begin{array}{l}\text { Group B } \\
\text { (PCM only) }\end{array}$ & $\begin{array}{l}\text { Group C } \\
\text { (PCM + } \\
\text { Silymarin) }\end{array}$ & $\begin{array}{l}\text { Group D } \\
\text { (PCM + 100mg/kg } \\
\text { Ficus exasperata) }\end{array}$ & $\begin{array}{l}\text { Group E } \\
\text { (PCM + 200mg/kg } \\
\text { Ficus exasperata) }\end{array}$ \\
\hline AST (IU/L) & $16.75 \pm 2.66$ & $67.25 \pm 6.66^{1}$ & $19.25 \pm 2.14^{2}$ & $40.50 \pm 3.10^{1,2}$ & $30.00 \pm 10.98^{1,2}$ \\
ALT (IU/L) & $20.25 \pm 1.38$ & $82.50 \pm 4.41^{1}$ & $23.00 \pm 1.47^{2}$ & $31.50 \pm 3.23^{2}$ & $32.50 \pm 8.54^{2}$ \\
ALP (IU/L) & $35.75 \pm 2.10$ & $127.75 \pm 4.50^{1}$ & $37.75 \pm 2.30^{2}$ & $53.25 \pm 5.76^{1,2}$ & $37.00 \pm 9.48^{2}$ \\
TP (Mg/dl) & $6.75 \pm 0.16$ & $3.90 \pm 0.13^{1}$ & $6.78 \pm 0.18^{2}$ & $5.55 \pm 0.06^{2}$ & $5.83 \pm 0.28^{2}$ \\
\hline
\end{tabular}

Values are expressed as means $( \pm S E M)$ of 5 rats in each group. 'significantly different $(p<0.05)$ from control group $;{ }^{2}$ significantly different $(p<0.05)$ from Paracetamol $(P C M)$ group $B$

\section{Histology Results}

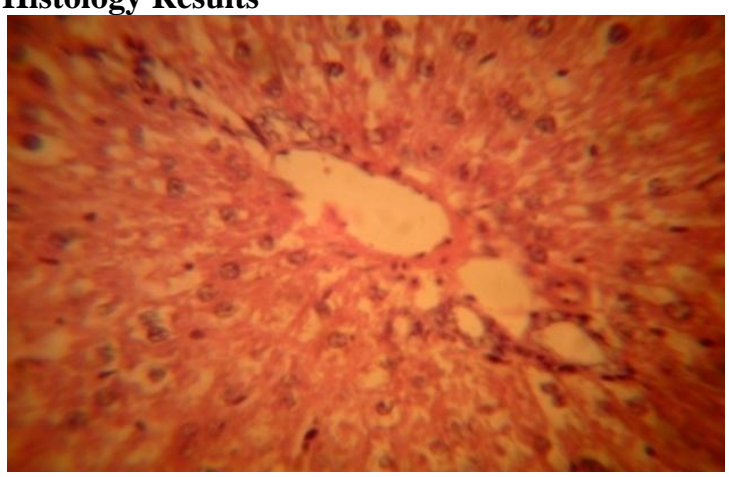

Plate 1: Liver tissue (Group A) showing normal architecture of portal tract and Normal Hepatocytes. (H\&E x 400)

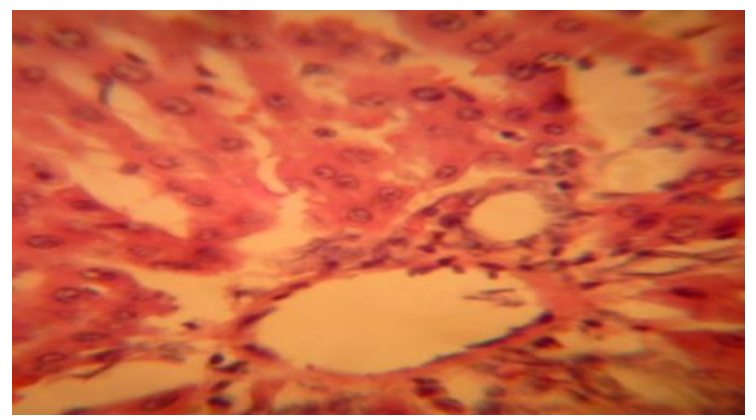

Plate 3: Liver Tissue (Group C treated with $50 \mathrm{mg} / \mathrm{kg}$ Silymarin and $800 \mathrm{mg} / \mathrm{kg}$ paracetamol) with better architecture showing mild portal area, mild tissue separation (H\&E x 400)

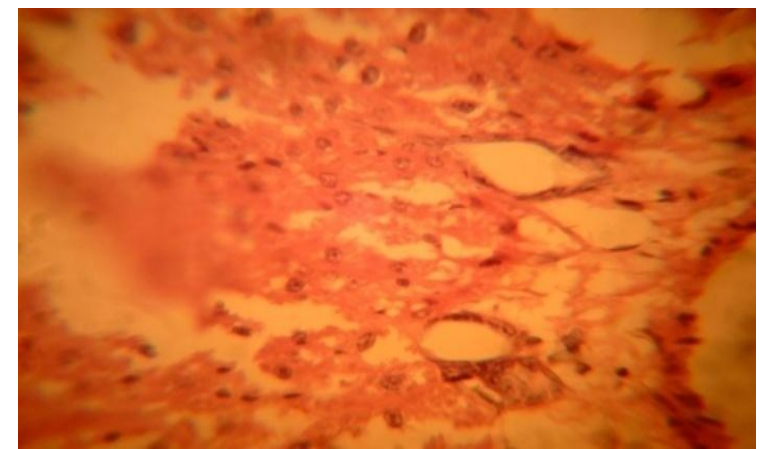

Plate 2: Liver tissue (Group B treated with Paracetamol 800mg/kg) showing necrosis of hepatocyte, severe distortion of the liver parenchymal and severe tissue seperation. (H\&E x 400)

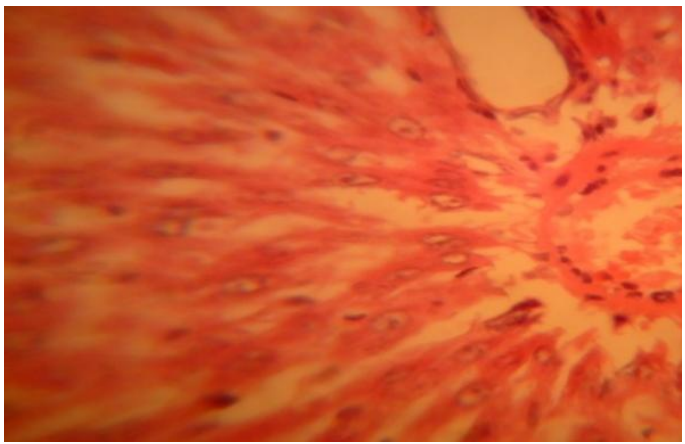

Plate 4: Liver Tissue (Group D treated with 100mgkg Ficus exasperata stem bark extract and $800 \mathrm{mg} / \mathrm{kg}$ Paracetemol showing portal vein congestion and moderate tissue separation (H \&E X 400)

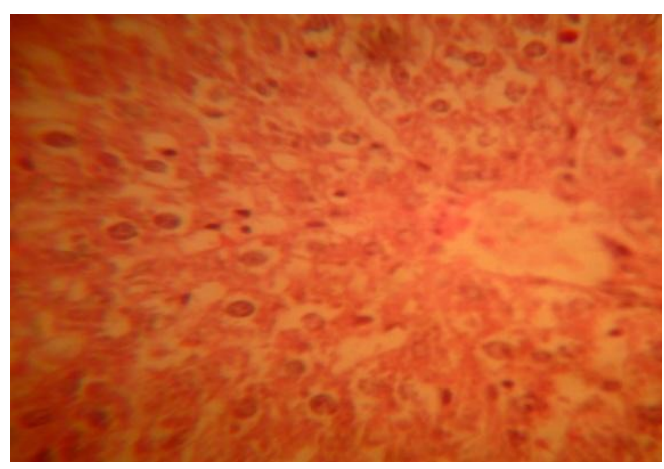

Plate 5: Liver tissue (Group E treated with $200 \mathrm{mg} / \mathrm{kg}$ Ficus exasperata stem bark extract and $800 \mathrm{mg} / \mathrm{kg}$ Paracetamol) showing mild portal congestion and better liver architecture (H\&E x 400) 
Drug induced liver injury has become a serious health problem in contemporary society, regrettably there are only a few drugs with serious side effects available for the treatment of liver ailments (Guntupalli et al. 2006). This therefore makes various researches on the mechanism and prevention of drug-induced liver injury very useful. Our histology results shows enormous liver tissue damage in the Paracetamol treated group which was also found to be reduced in groups that were administered with stem bark extracts of Ficus exasperata. The histology of the normal control group (Plate 1) showed normal portal tract, central vein and normal hepatocytes. The histological findings showed that there was visible distortion in the architecture of the liver tissue due to the administration of Paracetamol (Plate 2). These distortions were less visible on tissue sections of animals pretreated with silymarin. On treatment with both doses of Ficus exasperata, sections (Plates 4-5) began to show better architecture as compared to Paracetamol treated groups. Serum Alkaline Phosphatase (ALP), Alanine Aminotransferase (ALT), Aspartate Aminotransferase (AST) and Total Protein (TP) activities were also assessed to corroborate and evaluate the hepatic functions (Degirmenchi et al. 2002). The increase in aminotransferases levels may be due to the cellular damage in the liver caused by Paracetamol induced hepatotoxicity. Various experimental studies have shown that subtle membrane changes are sufficient to allow passage of intracellular enzymes to the extracellular space (Garella 1997). Cell damage increases permeability causing cytosolic isoenzymes to spill into the sinusoids and from there into the peripheral blood (Garella 1997). Ezeonwu (2013), had earlier reported an increase in AST, ALT and ALP in Paracetamol hepato-nephrotoxicity in rats. The research work of Syed et al. (2012) also showed that administration of $\mathrm{CCl} 4$ to normal rats increased serum levels of AST, ALT, ALP, and bilirubin. Salimuddin et al. (2008) reported that alterations in hepatic function may be because of increase activity and mRNA levels of araginase. These earlier reports therefore made evaluation of ALT, AST, ALP and TP activities necessary for our assessment of hepatocellular dysfunction. Consequently, the results of our study showed that Paracetamol induced toxicity in rats produced alterations in the hepatic functions as well as the histology of liver tissue. The increase in the levels of AST, ALT and ALP in diabetic rats after treatment for 14 days had been reported earlier by Arhoghro (2009). The reversal of increased serum enzymes in Paracetamol-induced liver damage by the extract may be an indication of its alleviation of plasma membrane damage or its membrane stabilizing activity thus preventing the leakage of intracellular enzymes. The effective control of total protein (TP) can be attributed to an improvement in the hepatic cells secretory mechanisms. Preliminary phytochemical screening indicated the presence of tannins, saponins and flavonoids (Bafor et al. 2009; Adebayo et al 2009). The antioxidant and hepatoprotective activities of flavanoids (Yoshikawa et al. 2003) and Saponins (Baek et al. 1996) are well known. This goes to strengthen our belief that the hepatoprotective activity of the extract may in also be due to the presence of Flavonoid and Saponin compounds. In conclusion, aqueous stem bark extracts of Ficus exasperata had protective effects on liver damage induced by high doses of Paracetamol. Isolation of the active principles majorly responsible for its hepatoprotective activity are recommended to corroborate our findings.

\section{REFERENCES}

Abbiw T (1990). Study of tropical shrubs and plants. J Biog. 23: 591-602.

Adebayo EA, Ishola OR, Taiwo OS, Majolagbe ON, Adekeye BT (2009). Evaluations of the methanol extract of Ficus exasperata stem bark, leaf and root for phytochemical analysis and antimicrobial activities. Afr J. Plt Sci. 3(12): 283-287,

Arhoghro EM, Ekpo KE, Ibeh GO (2009). Effect of aqueous extract of scent leaf (Ocimum gratissimum) on carbon tetrachloride (CCl4) induced liver damage in albino Wister rats. Afr J Pharm Pharmacol. 3(11): 562-567

Baek NL, Kim YS, Kyung JS, Park KH (1996). Isolation of Antihepatotoxic agent from the roots of Astragalus membranaceous. Korean J. Phamacog. 27: 111117.

Bafor EE, Nwiko M, Omogbai EK, Ozolua RI, Nworgu ZA (2009). Evaluation of the proposed inhibitory effect of the aqueous stem-bark extract of ficus exasperata on uterine preparations in vitro. Int. J. Pharmacol., 5: 94-97.

Buniyamin AA, Eric KI, Fabian CA (2007). Pharmacognosy and Hypotensive evaluation of Ficus exasperata Vahl (moraceae) leave. Acta Poloniae Pharm-Drug Res. 64(6): 543-546.

Cousins ON, Micheal AH (2002). Medicinal properties in the diet of Gorillas. An ethno-

${ }^{l}$ ENOGIERU, AB; ${ }^{l}$ CHARLES, YO $;{ }^{l}$ OMORUYI, SI; ${ }^{l}$ MOMODU, OI; ${ }^{l}$ EZEUKO, VC 
pharmacological evaluation. Afr. Stud. Monogr. 23(2): 65-89.

Degirmenchi I, Kalender S, Ustuner MC, Kalender Y, Gunes HV, Unal N, Basaran A (2002). The effects of acarbose and Rumex patientia on liver ultrastructure in streptozotocin-induced diabetic (type-II) rats. Drugs Exp. Clin. Res. 28: 229-234.

Drury RAB, Wallington EA, Cameron RC (1976). Histological techniques: 4th ed., Oxford University Press NY. U.S.A. pp. 279-280.

Ezeonwu VU, Dahiru D (2013). Protective Effect of Bi-Herbal Formulation of Ocimum gratissimum and Gongronema latifolium Aqueous Leaf Extracts on Acetaminophen-induced HepatoNephrotoxicity in Rats. American J Biochem. 3(1): 18-23

Garella S (1997). The cost of dialysis in the USA. Nephrol. Dial. Transplant. 12:10-2.

Guntupalli M, Chandana V, Pushpangadan P, Shirwaiker AI (2006). Hepatoprotective effects of rubiadin, a major constituent of Rubia cordifolia Linn. J. Ethnopharmacol. 103: 484-490.

Hallan P (1999). Population dynamics of Fig wasps from Ficus exasperata Vahl. Proc. Kon, ned. Akad-we ser. C. 87:365-375.

Ijeh II, Agbor C (2006). Body and organ weight changes following administration of aqeous extracts of Ficus exasperata Vahl on white albino rats. J anim vet adv. 5(4): 277-279.

Keay RWJ, Onochie CFA. (1964). Nigeria Trees. Dept. For. Res. 1\&2: 389-390.

Meyer SA, Kulkarni AP (2001). Hepatotoxicity. In: Hodgson E, Smart RC (Eds.), Introduction to
Biochemical Toxicology. 3rd ed. John Wiley and sons, New York. 487- 490.

Mitra SK, Seshadri SJ, Venkantarangama MV, Gopumadhavan S, Sarma DN (2000). Effect of HD-03- a herbal formulation in galactosamineinduced hepatopathy in rats. Indian J. Physiol. Pharmacol. 44:82-86.

Odunbaku OA, Ilusanya OA, Akasoro KS (2008). Antibacterial activity of ethanolic leaf extract of Ficus exasperata on Escherichia coli and Staphylococcus albus. Sci. Res. Essay 3(11): 562564.

Reitman S, Frankel SA (1957). Colorimetric method for the determination of serum levels of glutamic oxaloacetic acid and pyruvic acid transaminases. Am. J. Clin. Pathol. 10:394-399

Salimuddin, Upadhyaya KC, Baquer NZ (2008). Effects of vanadate on expression of liver araginase in experimental diabetic rats. IUBMB Life, 48(2):237-40.

Sonibare MO, Isiaka AO, Taruka MW, Williams NS, Soladoye M, Emmanuel O. (2006). Constituents of Ficus exasperata leaves. Natural product communications pp.23-26.

Syed AB, Iqbal MM, Kiranmai M, Ibrahim M. (2012). Hepatoprotective Activity of Phyllanthus Amarus Seeds Extracts in CCl4 Treated Rats: In Vitro \& In Vivo. J. Med. Res. 12(6):38-49

Yoshikawa M, Morikawa T, Kashima Y, Ninomiya K, Matsuda H (2003). Structure of new dammaranetype triterpene Saponins from the flower buds of Panaxnotoginseng and hepatoprotective effect of Principal Ginseng Saponins. J. Nat. Prod. 66(7): 922-927. 